\title{
Parental views of antibiotic use in children with upper respiratory tract infections in Jordan
}

\author{
Rana Abu Farha ${ }^{1 *}$, Maysa Suyagh ${ }^{2}$, Lina Alsakran ${ }^{3}$, Mervat Alsous $^{1}$ and Eman \\ Alefishat $^{2}$ \\ ${ }^{1}$ Department of Clinical Pharmacy and Therapeutics, Faculty of Pharmacy, Applied Science Private University, Amman, Jordan, \\ ${ }^{2}$ Department of Biopharmaceutics and Clinical Pharmacy, Faculty of Pharmacy, The University of Jordan, Amman, Jordan, \\ ${ }^{3}$ Department of Pharmacy and Nutrition, University of Saskatchewan, Saskatoon, Canada
}

*For correspondence: Email: r_abufarha@asu.edu.jo, abufarharana@yahoo.com; Tel: 0096265609957 ext 1496; Fax: 009625232899

\begin{abstract}
Purpose: To assess the knowledge, attitudes and practices of parents towards antibiotics use for upper respiratory tract infections (URTIs) in Jordan.

Methods: A cross-sectional study was carried out at 10 private outpatients' pediatric clinics across Amman-Jordan from September to December 2013. During the study period, 1329 parents of young children who fulfilled the inclusion criteria and agreed to participate were interviewed, and completed a validated structured questionnaire.

Results: A large proportion of parents (903, $68 \%)$ believed that weather change was the main cause of acute URTIs in their children. Although 1098 (82.8\%) of parents were aware that the recurrent use of antibiotics leads to a decrease in effectiveness due to bacterial resistance, 859 (64.6\%) of the respondents reported that they would give antibiotics without prescription. Fathers (135, 40.2\%), were significantly more aware that URTIs follow its natural course without antibiotic administration compared to mothers $(N=327,32.9 \%)$, respectively $(p=0.005)$.

Conclusion: There is a lack of adequate parental knowledge concerning the use and misuse of antibiotics in children in Jordan. National publicity campaign should be mounted to improve awareness. Furthermore, existing laws should be enforced to prevent parents from purchasing antibiotics over-thecounter (OTC).
\end{abstract}

Keywords: Antibiotics, Attitude, Knowledge, Parents, Upper respiratory tract infections, Publicity campaign

Tropical Journal of Pharmaceutical Research is indexed by Science Citation Index (SciSearch), Scopus, International Pharmaceutical Abstract, Chemical Abstracts, Embase, Index Copernicus, EBSCO, African Index Medicus, JournalSeek, Journal Citation Reports/Science Edition, Directory of Open Access Journals (DOAJ), African Journal Online, Bioline International, Open-J-Gate and Pharmacy Abstracts

\section{INTRODUCTION}

Acute upper respiratory tract infections (URTI)s is one of the most common acute infections affecting children worldwide, where children may suffer from more than 5 infections per year [1]. Despite the predominantly viral cause [2], antibiotics are frequently and commonly prescribed and misused in children with symptoms of acute URTI [2]. It is reported that 46 $\%$ of children with an URTI in the United States were prescribed antibiotics [3], where another study in England reviewed that approximately 70 $\%$ of all antibiotics were prescribed for URTIs [4].

Antibiotics misuse is considered one of the major public health issues worldwide, and it is an important factor contributing to the development 
of antibiotic resistance in pediatric patients with URTI [5,6]. This will place an excessive burden on the health economy due to infections and bacterial resistance which require more specific and expensive antibiotics to treat $[5,6]$. In addition, the misuse of antibiotics will lead to the development of side effects from unnecessary antibiotic use [5].

Factors contributing to antibiotic misuse in children are complex; including parental attitude, physician beliefs, high incidence of infectious diseases in children, the lack of access to health care, costs and poor regulatory controls on the use of prescription drugs such as antibiotics, coupled with low antibiotic knowledge prompting increased self-medication with these drugs $[3,7,8]$.

Among the most important factors contributing to inappropriate antibiotic prescription are parental knowledge and attitudes. Many pediatricians feel pressured by parents to prescribe more antibiotics than necessary [9-11]. It is necessary that parents and caregivers have the appropriate knowledge to enable correct decisions of initiating the antibiotics with minimal unnecessary use.

In Jordan, many previous studies have demonstrated irrational antibiotic use [12-14], and high prevalence of self-medication with antibiotics [14,15]. Unfortunately, antibiotics in Jordan can be dispensed without a doctor's prescription [16]. The impact of the open access to antibiotics on the overall health of Jordanian citizens needs to be assessed and highlighted. To the best knowledge of the researchers, there has been no study in Jordan that explored parental awareness, attitudes and practices regarding antibiotic use in children with URTI. Therefore the primary aim of this study is to assess the knowledge, attitudes and practices of parents in Jordan towards antibiotics for URTI.

\section{METHODS}

\section{Study design, settings and subjects}

This was a cross-sectional study that carried out across 10 private outpatients' pediatric clinics in Jordan. The study commenced in Septemper2013 and continued for four months. During the study period, 1329 parents of young children (less than 10 years of age) were included in the study. All eligible parents were recruited only after written informed consent had been obtained.
In order to gain the participation of as many parents as possible, a convenience sampling method was employed in the outpatient clinic over 4 months duration. The inclusion criteria were parents of children 10 years old or less, who are able to read and write Arabic, had no apparent cognitive deficit, and had an appointment at an outpatient clinic in the study sites. Ten research assistants (pharmacists) were trained to administer the questionnaire in the same manner (to decrease the risk of assessment bias). Finally the parents were interviewed and the required questionnaires were filled.

\section{Questionnaire development and pilot testing}

A pretested and validated questionnaire was developed to conduct this study. Pilot testing was done by distributing the questionnaire to 10 parents. Those parents were recruited to complete the validation process and to help finalize the structured questionnaire by eliminating or modifying unnecessary or ambiguous questions. Most questions were "Yes/No" or Likert scale in type.

The final form of the questionnaire consisted of parents' demographic data, and a number of questions that covered three main areas of interest. These areas included:

1) Assessment of parents' knowledge regarding URTI and use of antibiotics in children with URTI.

2) Parents' attitude toward antibiotic use in children with URTI.

3) Parents' practice on the use of antibiotics in children with URTI.

Parents' Knowledge section included 8 closed ended questions to assess knowledge of participants regarding antibiotics use in URTIs. Participants' response was either agreeing, uncertain, or disagrees. For each correct answer, patient gain one point and a total knowledge score out of eight was calculated.

\section{Ethical approval}

The study protocol was approved by the Scientific Research Ethical Committee at The University of Jordan (ref no. 1/21/2015/2016). The study was conducted following the ethical standards outlined in the World Medical Association Declaration of Helsinki guidelines [17]. Participant's confidentiality was preserved. 


\section{Data analysis}

Data was analyzed using statistical package for social science (SPSS) version 17 . The descriptive analysis was done using mean and SD for continuous variables and percentage for qualitative variables. Pearson Chi-square was used to calculate $p$-values for categorical variables. To evaluate the effect of parents' gender and education on the total knowledge score, analysis of data was carried out using simple linear regression analysis. For all statistical analysis, $p<0.05$ was considered statistically significant and all tests were twotailed.

\section{RESULTS}

A total of 1329 questionnaires were completed out of 1500 questionnaire distributed (response rate $88.6 \%$ ). Females represented $74.7 \%$ (993) of the study sample, while males represent 25.3 $\%$ (336). Parents were between 17 and 72 years of age and most of them were not from the medical field. The majority had a bachelors' degree and had intermediate income (900, $69 \%)$ and $(881,67.1 \%)$ respectively). Sixty five percent of the sample was insured. The demographic details of the sample are summarized in Table 1.
When parents were asked about the causes of URTIs, 903 (68\%) believed that weather change was the main cause of acute URTIs in their children. The remaining thought that URTIs were caused by germs $(372,28 \%)$, followed by ingestion of certain foods $(27,2.0 \%)$. Only 27 $(2.0 \%)$ parents stated they did not know the cause of URTIs.

Parents were asked about conditions requiring antibiotic prescription in children. About 1287 (96.8\%), $1275(95.9 \%)$ and $1233(92.8 \%)$ of parents believed that antibiotics were needed for sore throat, ear pain and fever, respectively, in a child with acute URTI. Parents also thought that antibiotics were necessary for cough $(1141,85.9$ $\%)$, vomiting (1019, $76.7 \%)$, common cold (982, $73.9 \%)$ and nose drainage (939, $70.7 \%)$, respectively. A significant proportion of parents in the present study had misconceptions that could contribute to the inappropriate use of antibiotics.

When evaluating parents' knowledge regarding the use of antibiotic in children with URTI, of a maximum score of eight the overall mean knowledge score was $4.2 \pm 2.1$. Only 587 (44.2 $\%)$ of the respondents were aware that antibiotics should not always be prescribed when a child suffers from a fever. Six hundred and twenty $(46.7 \%)$ parents knew that most URTIs do not need antibiotics to heal.

Table 1: Demographic characteristics for parents $(N=1329)$

\begin{tabular}{|c|c|}
\hline Parameter & Results $^{*}$ \\
\hline \multicolumn{2}{|l|}{ Age (years) } \\
\hline \multirow{2}{*}{\multicolumn{2}{|c|}{ Gender $\mathbf{N}(\%)$}} \\
\hline & \\
\hline Females & $993(74.7 \%)$ \\
\hline \multirow{2}{*}{\multicolumn{2}{|c|}{ Occupation $N(\%)$}} \\
\hline & \\
\hline From the medical field & 169 (3.1\%) \\
\hline . Others & $1122(86.9 \%)$ \\
\hline \multicolumn{2}{|l|}{ Number of children } \\
\hline mean $\pm(S D)$, [range] & $3.34 \pm(1.73)[1-11]$ \\
\hline \multicolumn{2}{|l|}{ Education; $N(\%)$} \\
\hline Not educated & $14(1.1 \%)$ \\
\hline - Primary school & $32(2.5 \%)$ \\
\hline - Secondary school & $357(27.4 \%)$ \\
\hline - Bachelor & $781(59.9 \%)$ \\
\hline - Masters & $84(6.4 \%)$ \\
\hline - $\mathrm{PhD}$ & $35(2.7 \%)$ \\
\hline \multicolumn{2}{|l|}{ Income level } \\
\hline - Very high & $27(2.1 \%)$ \\
\hline - High & $266(20.3 \%)$ \\
\hline - Intermediate & $881(67.1 \%)$ \\
\hline - Good & $109(8.3 \%)$ \\
\hline - Low & $30(2.3 \%)$ \\
\hline Insurance; [Insured, N (\%)] & $852(65.6 \%)$ \\
\hline
\end{tabular}

*Some parents didn't answer all questions. So the total number is different for each section 
About 469 (35.6\%) of the respondents believed that an URTI follows its natural course without antibiotic administration, and 696 (52.4\%) of them thought that antibiotics are effective in curing all types of microbial infections (both viral and bacterial).

Most of the study sample (1098, $82.8 \%)$ were aware that the recurrent use of antibiotics leads to a decrease in effectiveness due to bacterial resistance. Also 871 (85.8\%) of the participants knew that antibiotics are not always safe to use, and around 1001 (75.4 \%) knew that antibiotics are associated with side effects. The distribution of parent responses to items that text their knowledge toward antibiotic use in URTI are as shown in Table 2.

It was obvious that higher proportion of mothers compared to fathers incorrectly believed that antibiotics should always be prescribed when a child suffers from fever and that URTI is cured more quickly if treated with antibiotics ( $p=0.028$ and 0.001 respectively). Results showed that fathers were more aware that antibiotics are not effective in curing all types of microbial infections (both viral and bacterial) and that URTIs follow its natural course without antibiotic administration ( $p$ $=0.000$ and 0.005 respectively). The results are presented in Table 3.
The relation between the socio-demographic variables such as age and educational level on the overall knowledge score was assessed. Results showed a statistically significant positive correlation between overall knowledge and participant age and educational level $[r=0.078(p$ $=0.005)$ and $r=0.247(p=0.000)$ respectively]. In addition, parents were asked if they had the tendency to give their children antibiotics without a prescription to treat a suspected URTI, and it was clear that a higher proportion of parents (859, $64.6 \%)$ would give antibiotics without prescription.

For parents who reported that they may give their children antibiotics without prescription, we assessed the possible reasons for that. Table 4 shows that the main reason was because their children were previously treated with antibiotics for the same symptoms, or due to a pharmacist's recommendations. Parents were also assessed for what they may do if they thought that their pediatrician prescribed unnecessary antibiotics to their children. It was clear that $711(53.7 \%)$ of parents would not stop the medication by themselves, and they would follow the physician's prescription, $490(37.0 \%)$ will not give antibiotics to their children, 761 (57.6 \%) would change pediatrician because he/she gives antibiotics to their children too often, and 938 $(70.6 \%)$ would ask the pharmacist if the antibiotic were necessary.

Table 2: Parental knowledge toward antibiotic use in URTIs.

\begin{tabular}{|c|c|c|c|c|}
\hline Variable & $\begin{array}{c}\text { Agree } \\
\mathbf{N}(\%) \\
\end{array}$ & $\begin{array}{c}\text { Uncertain } \\
\text { N (\%) }\end{array}$ & $\begin{array}{c}\text { Disagree } \\
\mathbf{N}(\%) \\
\end{array}$ & $\begin{array}{l}\text { Total } \\
\mathbf{N}(\%) \\
\end{array}$ \\
\hline $\begin{array}{l}\text { 1. Antibiotics should always be prescribed when a } \\
\text { child suffers from fever. }\end{array}$ & $636(47.9 \%)$ & $105(7.9 \%)$ & $587(44.2 \%)$ & $1328(100 \%)$ \\
\hline 2. Most URTIs do not need antibiotics. & $620(46.7 \%)$ & $218(16.4 \%)$ & $489(36.9 \%)$ & $1327(100 \%)$ \\
\hline $\begin{array}{l}\text { 3. Children that suffer from URTIs recover more } \\
\text { quickly if treated with antibiotics. }\end{array}$ & $844(63.7 \%)$ & $146(11.0 \%)$ & $334(25.3 \%)$ & $1324(100 \%)$ \\
\hline $\begin{array}{l}\text { 4. An URTI follows its natural course without } \\
\text { antibiotic administration. }\end{array}$ & $469(35.6 \%)$ & $250(19.0 \%)$ & $599(45.4 \%)$ & $1318(100 \%)$ \\
\hline 5. Antibiotics are always safe when used. & $256(19.3 \%)$ & $197(14.9 \%)$ & $871(85.8 \%)$ & $1324(100 \%)$ \\
\hline $\begin{array}{l}\text { 6. Recurrent use of antibiotics leads to a decrease } \\
\text { in its effectiveness due to the development of } \\
\text { resistant bacteria. }\end{array}$ & $1098(82.8 \%)$ & $141(10.6 \%)$ & $87(6.6 \%)$ & $1326(100 \%)$ \\
\hline $\begin{array}{l}\text { 7. Antibiotics are effective in treatingall types of } \\
\text { microbial infections (both viral and bacterial). }\end{array}$ & $329(24.8 \%)$ & $303(22.8 \%)$ & $696(52.4 \%)$ & $1328(100 \%)$ \\
\hline 8. Antibiotics are free from side effects & $178(13.4 \%)$ & $149(11.2 \%)$ & $1001(75.4 \%)$ & $1328(100 \%)$ \\
\hline
\end{tabular}


Table 3: Differences in fathers' and mothers' knowledge regarding antibiotic use in URTIs

\begin{tabular}{|c|c|c|c|}
\hline Statement & $\begin{array}{c}\text { Female } \\
\text { Agreed } \\
\mathbf{N}(\%) \dagger\end{array}$ & $\begin{array}{c}\text { Male } \\
\text { Agreed } \\
\text { N (\%)† }\end{array}$ & $\begin{array}{c}\text { p-value } \\
\text { Pearson Chi- } \\
\text { square }\end{array}$ \\
\hline $\begin{array}{l}\text { 1. Antibiotics should always be prescribed when a child suffers from } \\
\text { fever. }\end{array}$ & $494(49.7 \%)$ & $138(41.1 \%)$ & $0.028^{*}$ \\
\hline 2. Most URTIs do not need antibiotics for treatment. & $463(46.6 \%)$ & $151(44.9 \%)$ & 0.993 \\
\hline $\begin{array}{l}\text { 3. Children that suffer from a URTI recover more quickly if treated } \\
\text { with antibiotics }\end{array}$ & $656(66.1 \%)$ & $179(53.2 \%)$ & $0.001^{*}$ \\
\hline 4. An URTI follows its natural course without antibiotic administration. & $327(32.9 \%)$ & $135(40.2 \%)$ & $0.005^{*}$ \\
\hline 5. Antibiotics are always safe when used. & $198(19.9 \%)$ & $54(16.1 \%)$ & 0.201 \\
\hline $\begin{array}{l}\text { 6. Recurrent use of antibiotics leads to a decrease in its effectiveness } \\
\text { due to the development of resistant bacteria. }\end{array}$ & $816(82.1 \%)$ & $272(80.9 \%)$ & 0.439 \\
\hline $\begin{array}{l}\text { 7. Antibiotics are effective in treating all types of microbial infections } \\
\text { (both viral and bacterial). }\end{array}$ & $269(27.1 \%)$ & $56(16.7 \%)$ & $0.000^{*}$ \\
\hline 8. Antibiotics are free from side effects & $129(13.0 \%)$ & $44(13.1 \%)$ & 0.771 \\
\hline
\end{tabular}

Note: 13 subjects did not determine their gender within the questionnaire, so they were excluded from this table. Significant difference ( $p$-value less than 0.05$) ; †$ Percentage within each group

Table 4: Reasons why some parents give antibiotics to their children without prescription. $\mathrm{N}=859$.

\begin{tabular}{|c|c|c|c|c|c|c|}
\hline Variable & Always & $\begin{array}{l}\text { Very } \\
\text { often }\end{array}$ & Sometimes & Rarely & Never & Total \\
\hline $\begin{array}{l}\text { Did not have the money to pay } \\
\text { for a pediatrician. }\end{array}$ & $\begin{array}{c}22 \\
(2.6 \%)\end{array}$ & $\begin{array}{c}62 \\
(7.2 \%)\end{array}$ & $\begin{array}{c}121 \\
(14.1 \%)\end{array}$ & $\begin{array}{c}158 \\
(18.4 \%)\end{array}$ & $\begin{array}{c}496 \\
(57.7 \%)\end{array}$ & $\begin{array}{c}859 \\
(100 \%)\end{array}$ \\
\hline $\begin{array}{l}\text { Did not have enough time to } \\
\text { visit the pediatrician. }\end{array}$ & $\begin{array}{c}83 \\
(9.7 \%)\end{array}$ & $\begin{array}{c}147 \\
(17.2 \%)\end{array}$ & $\begin{array}{c}232 \\
(27.1 \%)\end{array}$ & $\begin{array}{c}129 \\
(15.1 \%)\end{array}$ & $\begin{array}{c}265 \\
(31.0 \%)\end{array}$ & $\begin{array}{c}856 \\
(99.6 \%)\end{array}$ \\
\hline $\begin{array}{l}\text { Did not think that it was serious } \\
\text { enough to visit the pediatrician. }\end{array}$ & $\begin{array}{c}138 \\
(16.1 \%)\end{array}$ & $\begin{array}{c}339 \\
(39.6 \%)\end{array}$ & $\begin{array}{c}248 \\
(29.0 \%)\end{array}$ & $\begin{array}{c}61 \\
(7.1 \%)\end{array}$ & $\begin{array}{c}70 \\
(8.2 \%)\end{array}$ & $\begin{array}{c}856 \\
(99.6 \%)\end{array}$ \\
\hline $\begin{array}{l}\text { In the past your child had been } \\
\text { treated with antibiotics for the } \\
\text { same symptoms. }\end{array}$ & $\begin{array}{c}210 \\
(24.6 \%)\end{array}$ & $\begin{array}{c}320 \\
(37.4 \%)\end{array}$ & $\begin{array}{c}173 \\
(20.2 \%)\end{array}$ & $\begin{array}{c}63 \\
(7.4 \%)\end{array}$ & $\begin{array}{c}89 \\
(10.4 \%)\end{array}$ & 855 (99.5) \\
\hline $\begin{array}{l}\text { Because a pharmacist } \\
\text { recommended it. }\end{array}$ & $\begin{array}{c}143 \\
(16.6 \%)\end{array}$ & $\begin{array}{c}231 \\
(26.9 \%)\end{array}$ & $\begin{array}{c}209 \\
(24.3 \%)\end{array}$ & $\begin{array}{c}113 \\
(13.2 \%)\end{array}$ & $\begin{array}{c}163 \\
(19.0 \%)\end{array}$ & $\begin{array}{c}859 \\
(100 \%)\end{array}$ \\
\hline $\begin{array}{l}\text { Because a friend/relative } \\
\text { recommended it. }\end{array}$ & $\begin{array}{c}41 \\
(4.8 \%)\end{array}$ & $\begin{array}{c}83 \\
(9.7 \%)\end{array}$ & $\begin{array}{c}137 \\
(15.9 \%)\end{array}$ & $\begin{array}{c}187 \\
(21.8 \%)\end{array}$ & $\begin{array}{c}411 \\
(47.8 \%)\end{array}$ & $\begin{array}{c}859 \\
(100 \%)\end{array}$ \\
\hline
\end{tabular}

\section{DISCUSSION}

The development of bacterial resistance to antibiotics represents a major hazard affecting the health of pediatric patients with URTIs $[5,6,18]$. This is due to the fact that antibiotics are frequently prescribed and misused for children with symptoms of acute URTI despite its viral aetiology [2]. This study was intended to collect data from parents to reflect their knowledge and attitudes towards antibiotic use in children with URTI within the Jordanian community.
The results of this study showed the insufficient awareness of parents regarding the causes of URTIs, in which only a few realized that germs are the main causative agents for such infections, whereas the majority of parents thought that weather conditions and seasonal changes are the main factors. The results of this study are consistent with values reported in a previous study [9], in which around $59 \%$ of Malaysian parents thought that weather change, is the main reason for URTIs while only $27.1 \%$ 
knew that infections are caused by germs. This mistaken belief may be due to cultural beliefs, in which parents think that when exposed to cold weather, their children would be more prone to have an URTI.

Our survey also suggests that parents have misconceptions about proper indications for antibiotics, where most of them believed that antibiotics were needed for sore throat, ear pain, fever, cough, vomiting, common cold and nose drainage. This was familiar to results presented by Chan and Tang [9], where they showed that more than $50 \%$ of parents have misunderstandings regarding when antibiotics should be indicated. This illustrates that parents believe that antibiotics act as miracle drugs and they should be prescribed for many indications whether a bacterial infection is present or not. This is similar to a recent work by Zyoud et al where they indicated that parents believed that antibiotics were helpful also in the treatment of fever associated with the infection [19].

The majority of parents believe that antibiotics should always be prescribed when a child suffers from fever. Also, they believe that most URTIs require antibiotics to cure them fast despite its viral origin $[2,19]$. Furthermore, some parents thought that antibiotics are effective in treating all types of microbial infections and are free from side effects. These misconceptions are similar to those presented by a previous study $[19,20]$.

When gender was taken into account, it was evident that fathers were more aware of the correct use of antibiotics; this may be due to the fact that mothers are more emotional and seek any solution when they see their children sick and they believe that antibiotics may be the miracle to make them better. It was evident that the older the parents and the more educated the better the knowledge regarding antibiotics prescription in URTI, which suggests the role of educational courses on improving the overall practice towards antibiotics use in children with URTI.

The previous mistaken beliefs resulted in antibiotic abuse, in which around $65 \%$ of the study sample reported that they tend to use antibiotics without a physician's prescription even though most of the parents knew that the recurrent use of antibiotics leads to the development of resistant bacteria. This concurs with results from a survey by the Pediatric Infectious Disease Society of Philippines, where $41.6 \%$ of caregivers self-medicate their children with antibiotics without physician referral [11]. When reasons for self-medications were assessed, it was obvious that parents found it easier to consult pharmacists as well as they depend on their experience in prescribing antibiotics.

In the current study, another malpractice was experienced by parents as they did not give their children antibiotics if they thought that it was unnecessary. Some parents said that they may stop the medication by themselves, others may change pediatrician, or would ask the pharmacist if the antibiotic were necessary. This action, as well as self-medication of antibiotics, indicates the lack of appropriate and effective communication between physicians and parents that may increase the incidence of antibiotic resistance.

Several studies on the concept of judicious use of antimicrobials in the treatment of URTI in children have been performed, many of which had focused on parental knowledge, awareness, and how to correct for malpractice $[9,10,19]$. In a survey from the United States $78 \%$ of pediatricians believed that educating parents on appropriate indications for antibiotic use may reduce inappropriate antibiotic prescribing [21]. Another study also concluded that a comprehensive educational program for clinicians and parents led to community-wide reductions in antibiotic prescribing and can reduce parents' expectation for antibiotic treatment [22].

The findings of this study has highlighted on a real and crucial problem that we face in Jordan which is purchasing antibiotics without a doctor's prescription in addition to the lack of parents' knowledge about the use of antibiotics; therefore there is a need for a law and regulation from the ministry of health in Jordan to control purchasing antibiotics without prescription from community pharmacies and improve the prescription attitudes of doctors and urge them to adhere to international clinical practice guidelines for use of antibiotics. Moreover, continuous education curriculum for parents via media and social media sites and updating paramedical information via programmed seminars would help to limit this problem.

In addition, the impact of using antibiotics as OTC drugs on rates of bacterial resistance in Jordan need to be assessed in future studies and compared with other countries which regulate antibiotics prescription. 


\section{Limitatıon of the study}

It is worth mentioning here the main methodological limitation of this study since as the questionnaire relied on parents' self-rated assessment of their own practice and knowledge, Parents might have felt pressured into completing the questionnaire or might have been unwilling to reveal their true practice deficiencies.

\section{CONCLUSION}

The findings of this study show that there is a lack of adequate parental knowledge about the use and misuse of antibiotics in their children, national publicity campaign - should be available for the general public, particularly the parents of young children, to help to differentiate between bacterial and viral infections and the ineffectiveness of treating viral infections with antibiotics. Furthermore, effective laws should be enforced to regulate access to antibiotics and prohibit parents from purchasing antibiotics over the counter.

\section{DECLARATIONS}

\section{Conflict of Interest}

No conflict of interest associated with this work.

\section{Contribution of Authors}

The authors declare that this work was done by the authors named in this article and all liabilities pertaining to claims relating to the content of this article will be borne by them.

\section{REFERENCES}

1. Bauman KA. The family physician's reasonable approach to upper respiratory tract infection care for this century. Arch Fam Med. 2000; 9(7): 596-597.

2. Earnshaw S, Monnet DL, Duncan B, O'Toole J, Ekdahl K, Goossens H. European Antibiotic Awareness Day, 2008 - the first Europe-wide public information campaign on prudent antibiotic use: methods and survey of activities in participating countries. Euro Surveill. 2009; 14(30): 19280.

3. Nyquist AC, Gonzales R, Steiner JF, Sande MA. Antibiotic prescribing for children with colds, upper respiratory tract infections, and bronchitis. JAMA. 1998; 279(11): 875-877.

4. Majeed A, Moser K. Age- and sex-specific antibiotic prescribing patterns in general practice in England and Wales in 1996. Br J Gen Pract. 1999; 49(446): 735-736.

5. Gyssens IC. Quality measures of antimicrobial drug use. Int J Antimicrob Agents. 2001; 17(1): 9-19.
6. Harnden A, Perera $R$, Brueggemann AB, Mayon-White $R$, Crook DW, Thomson A, Mant D. Respiratory infections for which general practitioners consider prescribing an antibiotic: a prospective study. Arch Dis Child. 2007; 92(7): 594-597.

7. Mangione-Smith R, McGlynn EA, Elliott MN, McDonald L, Franz CE, Kravitz RL. Parent expectations for antibiotics, physician-parent communication, and satisfaction. Arch Pediatr Adolesc Med. 2001; 155(7): 800-806.

8. Coco AS, Horst MA, Gambler AS. Trends in broadspectrum antibiotic prescribing for children with acute otitis media in the United States, 1998-2004. BMC Pediatr. 2009; 9: 41.

9. Chan GC, Tang SF. Parental knowledge, attitudes and antibiotic use for acute upper respiratory tract infection in children attending a primary healthcare clinic in Malaysia. Singapore Med J. 2006; 47(4): 266-270.

10. Rousounidis $A$, Papaevangelou V, Hadjipanayis $A$, Panagakou S, Theodoridou M, Syrogiannopoulos G, Hadjichristodoulou C. Descriptive study on parents' knowledge, attitudes and practices on antibiotic use and misuse in children with upper respiratory tract infections in Cyprus. Int J Environ Res Public Health. 2011; 8(8): 3246-3262.

11. Salonga MJC. Belıefs and practices of parents on the use of antibıotics for their chıldren with upper respıratory tract infectıon. PIDSP J. 2009; 10: 1.

12. Al-Bakri AG, Bustanji Y, Yousef AM. Community consumption of antibacterial drugs within the Jordanian population: sources, patterns and appropriateness. Int $J$ Antimicrob Agents. 2005; 26(5): 389-395.

13. Al-Azzam SI, Al-Husein BA, Alzoubi F, Masadeh MM, AlHorani MA. Self-medication with antibiotics in Jordanian population. Int J Occup Med Environ Health. 2007; 20(4): 373-380.

14. Sawair FA, Baqain ZH, Abu Karaky A, Abu Eid R. Assessment of self-medication of antibiotics in a Jordanian population. Med Princ Pract. 2009; 18(1): 2125.

15. WHO. Pharmacovigilance: ensuring the safe use of medicines. WHO Policy Perspectives on Medicines, Geneva, Switzerland; 2004 http://whqlibdocwhoint/hq/ 2004/WHO_EDM_20048pdf. 2004.

16. Almaaytah A, Mukattash TL, Hajaj J. Dispensing of nonprescribed antibiotics in Jordan. Patient Prefer Adherence. 2015; 9: 1389-1395.

17. World Medical A. World medical association declaration of Helsinki: Ethical principles for medical research involving human subjects. JAMA. 2013; 310(20): 21912194.

18. Mangione-Smith $R$, Zhou C, Robinson JD, Taylor JA, Elliott MN, Heritage J. Communication Practices and Antibiotic Use for Acute Respiratory Tract Infections in Children. Ann Fam Med. 2015; 13(3): 221-227.

19. Zyoud Se, Abu Taha A, Araj K, Abahri I, Sawalha A, Sweileh W, Awang R, Al-Jabi S. Parental knowledge, attitudes and practices regarding antibiotic use for acute

Trop J Pharm Res, September 2016; 15(9): 2015 
upper respiratory tract infections in children: a crosssectional study in Palestine. BMC pediatr. 2015; 15(1): 176.

20. Parimi N, Pinto Pereira LM, Prabhakar P. Caregivers' practices, knowledge and beliefs of antibiotics in paediatric upper respiratory tract infections in Trinidad and Tobago: a cross-sectional study. BMC Fam Pract. 2004; 5: 28.
21. Bauchner H, Pelton SI, Klein JO. Parents, physicians, and antibiotic use. Pediatr. 1999; 103 (2): 395-401.

22. Belongia EA, Sullivan BJ, Chyou PH, Madagame E, Reed KD, Schwartz B. A community intervention trial to promote judicious antibiotic use and reduce penicillinresistant Streptococcus pneumoniae carriage in children. Pediatr. 2001; 108(3): 575-583. 